\title{
Peningkatan Pemahaman Konsep Bilangan Bulat Melalui Cerita Si Unyil Berbasis ICT
}

\author{
Lisnani $^{*}$ dan Yohanes H Pranoto ${ }^{2}$ \\ ${ }^{1 *}$, Pendidikan Guru Sekolah Dasar, Universitas Katolik Musi Charitas \\ Jalan Bangau No. 60, Palembang, Sumatera Selatan, Indonesia \\ 1*lisnani@ukmc.ac.id
}

Artikel diterima: 30-11-2019, direvisi: 26-05-2020, diterbitkan: 31-05-2020

\begin{abstract}
Abstrak
Hasil belajar siswa yang dibawah standar menunjukkan siswa kurang memahami konsep pada materi bilangan bulat. Penelitian ini bertujuan meningkatkan pemahaman konsep siswa pada materi bilangan bulat melalui penggunaan media pembelajaran yaitu cerita Si Unyil berbasis ICT, yang terlihat dari peningkatan hasil belajar siswa. Jenis penelitian ini yaitu penelitian kualitatif yaitu Penelitian Tindakan Kelas (PTK). Siklus yang terjadi dalam PTK terdiri dari dua siklus, dimana tiap siklus terdiri dari empat tahapan: perencanaan, tindakan, pengamatan, dan refleksi. Subjek penelitian adalah siswa kelas VIIA SMP Xaverius 6 Palembang yang berjumlah 26 orang. Data penelitian dikumpulkan menggunakan lembar observasi, tes, dan dokumentasi. Deskriptif kualitatif digunakan untuk menganalisa data observasi dan dokumentasi. Sedangkan deskriptif kuanlitatif yaitu menganalisa hasil tes. Hasil dari penelitian ini berupa peningkatan pemahaman konsep terlihat dari meningkatnya hasil belajar siswa dari siklus pertama sebesar 57,84 meningkat pada siklus kedua menjadi 71,19.

Kata Kunci: pemahaman konsep, cerita Si Unyil, peneltian kualitatif, PTK, ICT.
\end{abstract}

\section{Improved Understanding Concept of Integers Through ICT-Based Si Unyil Story}

\begin{abstract}
Under-standard learning outcomes of students show students do not understand the concepts in integer material. This study aims to increase students' understanding of the concepts of integers through the use of instructional media, namely the ICT-based Si Unyil story, which can be seen from the increase in student learning outcomes. This type of research is qualitative research, Classroom Action Research (CAR). The cycle that occurs in CAR consists of two cycles, where each cycle consists of four stages: planning, action, observation, and reflection. The subjects of the study were the students of class VIIA Xaverius 6 Palembang Junior High, totaling 26 people. Research data were collected using observation sheets, tests, and documentation. Qualitative descriptive is used to analyze observation and documentation data. While quantitative descriptive analysis of test results. The results of this study in the form of an increased understanding of the concept can be seen from the increase in student learning outcomes from the first cycle of 57.84 increased in the second cycle to 71.19.

Keywords: the concept of understanding, Si Unyil's story, qualitative research, classroom action research, ICT.
\end{abstract}




\section{Pendahuluan}

Salah satu tantangan yang dihadapi oleh seorang guru adalah bagaimana memusatkan perhatian siswa dan membuat siswa tertarik terhadap materi yang disampaikan di dalam kelas (Hartati, 2018). Khususnya pada mata pelajaran yang dianggap sulit dan tidak menyenangkan seperti Bahasa Inggris.

Mata pelajaran yang dianggap sulit lainnya adalah Matematika. Dalam mempelajari matematika siswa diharapkan memiliki kemahiran matematika berupa kemampuan memahami konsep dan prosedur, penalaran, komunikasi, dan pemecahan masalah matematis (Asep, dkk., 2012).

Salah satu bagian penting dalam matematika adalah kemampuan pemecahan masalah matematika. Siswa cenderung sulit menjawab soal pemecahan masalah disebabkan oleh rendahnya pemahaman konsep matematika siswa (Afriansyah, 2016).

Pemahaman konsep merupakan landasan mendasar. Melalui penguasaan konsep, siswa akan lebih mudah dalam mempelajari matematika. Dengan penguasaan konsep yang baik, siswa dapat mencapai kemampuan mendasar lainnya, yaitu kemampuan bernalar, berkomunikasi, koneksi dan pemecahan masalah (Hartati, dkk, 2017).

Salah satu pemahaman konsep terhadap materi matematika yang diperlukan siswa adalah bilangan bulat. Bilangan adalah konsep matematika yang mendasari dan digunakan di hampir seluruh cabang matematika (NCTM, 2000).

Pemahaman konsep (conceptual understanding) didefinisikan sebagai kemahiran dalam mengonsepkan berbagai operasi dan hubungan antar elemen dalam matematika (Kilpatrick, Swafford, \& Findell, 2001; Ridia \& Afriansyah, 2019). Berdasarkan pemaparan dari beberapa tokoh, pemahaman konsep memungkinkan siswa untuk menerapkan dan mengadaptasikan beberapa ide matematika yang diperoleh untuk situasi baru. Peningkatan pemahaman konsep terlihat dari peningkatan hasil belajar siswa (Nuraeni \& Afriansyah, 2016).

Bilangan bulat tersusun atas bilangan bulat bernilai positif, bilangan bulat bernilai negatif, dan bilangan 0 (Wahyuningtyas, 2016). Bilangan bulat menurut Runtukahu dan Kandou (2014) adalah, bilangan yang terdiri dari 0 , bilangan positif dan bilangan negatif. Bilangan positif adalah bilangan yang nilainya bernilai positif setelah angka 0 (nol) sedangkan bilangan yang bernilai negatif sebelum angka 0 disebut bilangan bulat negatif.

Berdasarkan pengalaman beberapa peneliti sebelumnya terkait pemahaman konsep di beberapa sekolah diperoleh data sebagai berikut: Pertama, penelitian di SMPN 4 Langke Rembong diketahui pemahaman konsep matematika cenderung menurun. Di samping itu, peneliti juga melakukan wawancara kepada guru bidang studi matematika di 
SMP Xaverius 6 Palembang. Hasil yang diperoleh dari wawancara yaitu berupa temuan pemahaman konsep matematika siswa masih sangat rendah. Di samping itu, siswa kurang merespon pembelajaran matematika yang disampaikan guru (Firdaus \& Afriansyah, 2016; Brinus, dkk., 2019);

Kedua, berdasarkan pengamatan langsung di lapangan, pada kenyataannya sebagian besar siswa mengalami kesulitan terkait dengan kemampuan pemahaman konsep matematika. Siswa kurang mampu mengaplikasikan konsep yang telah dimilikinya. Di samping itu, data nilai ulangan yang didapat dari guru mata pelajaran matematika pada materi lingkaran Tahun Pelajaran 2013/2014 diketahui bahwa dari 6 kelas siswa itu nilai yang didapat masih dibawah KKM dari siswa yang ada baru 40\% siswa yang mencapai KKM (Warmi, 2019).

Proses pembelajaran tidak akan efektif dan menarik apabila guru hanya bercerita (ceramah) tentang hal-hal yang terjadi (Afriansyah, 2014). Maka, media yang dibutuhkan adalah berupa perantara yang dapat dipergunakan baik secara audio maupun visual oleh siswa (Ismawanto, 2014: 528). Maka dari itu, guna meningkatkan pemahaman konsep tentang bilangan bulat diperlukan media pembelajaran (Supriatna \& Afriansyah, 2018).

Menurut Sundayana (2015), media pendidikan atau media pembelajaran tumbuh dan berkembang sejalan dengan perkembangan teknologi pembelajaran. Salah satu media yang digunakan peneliti adalah cerita Si Unyil berbasis ICT. Penggunaan ICT dilakukan karena sejalan dengan revolusi industry 4.0.

Penelitian seperti ini pernah dilakukan oleh peneliti sebelumnya terkait dengan cara meningkatkan pemahaman konsep menggunakan media pembelajaran antara lain sebagai berikut: Pertama, penelitian yang dilakukan oleh Sapilin, dkk (2019) berjudul "Peningkatan Pemahaman Konsep Peserta Didik dengan Model Discovery Learning pada Materi Fungsi Invers" diperoleh hasil peningkatan pemahaman konsep peserta didik dengan model discovery learning pada materi fungsi invers. Kemampuan pemahaman konsep peserta didik mengalami peningkatan sebesar 20,41\%, sedangkan ketuntasan klasikal meningkat sebesar $17,15 \%$.

Kedua, penelitian yang dilakukan oleh Purwanti, dkk (2016) dengan judul "Pengaruh Pembelajaran Berbatuan Geogebra terhadap Pemahaman Konsep Matematis ditinjau dari Gaya Kognitif" diperoleh hasil penelitian yaitu terdapat pengaruh pembelajaran Discovery Learning berbantuan geogebra terhadap pemahaman konsep matematis.

Ketiga, penelitian yang dilakukan oleh Farida (2015) dengan judul "Mengembangkan Kemampuan Pemahaman Konsep Peserta Didik Melalui Pembelajaran Berbasis VCD", diperoleh hasil penelitian pembelajaran matematika 
dengan media VCD pembelajaran terhadap kemampuan memahami konsep terhadap siswa kelas IX di SMP Negeri 3 Bandar Lampung semester I padamateri pokok kesebangunan lebih efektif dibandingkan pembelajaran konvensional, hal ini terlihat dari kemampuan pemahaman konsep peserta didik yang lebih baik dibandingkan pembelajaran konvensional.

Adapun keistimewaan dari penelitian ini adalah peneliti menggunakan cerita $\mathrm{Si}$ Unyil berbasis ICT di dalam pembelajaran bilangan bulat dengan tujuan mengetahui peningkatan pemahaman konsep siswa pada materi bilangan bulat pada siklus pertama dan kedua.

\section{Metode}

Penelitian ini menggunakan metode penelitian kualitatif yaitu Penelitian Tindakan Kelas (PTK). Penelitian ini didesain dengan menggunakan model penelitian tindakan kelas model Spiral dari Kemmis dan Taggart dengan tahapan yang terdiri dari empat tahapan yang disebut PAOR yaitu: 1) perencanaan (planning); 2) tindakan (action); 3) pengamatan (observation); 4) refleksi (reflecting). Proses penelitian ini sama seperti langkahlangkah yang diterapka oleh Emzir (2012).

Penerapan penggunaan cerita si unyil berbasis ICT pada materi bilangan bulat dijadikan sebagai variabel independent. Kemampuan pemahaman konsep matematika pada materi bilangan bulat sebagai variable dependent. Penelitian ini dilakukan di SMP Xaverius 6 Palembang dengan subjek penelitiannya adalah siswa Kelas VII.A yang berjumlah 26 orang. Pelaksanaan kegiatan penelitian pada semester genap pada tahun pelajaran 2018/2019.

Peneliti mengumpulkan data menggunakan: 1) lembar observasi, untuk mengamati proses pembelajaran berlangsung; 2) tes untuk mengetahui tingkat pemahaman konsep siswa apakah telah mencapai target ketuntasan dengan tes essai; 3) catatan lapangan untuk mencatat serangkaian peristiwa yang terjadi di lapangan. Tindakan pada penelitian ini dikatakan berhasil apabila siswa telah mengalami peningkatan pemahaman konsep bilangan bulat pada pelajaran Matematika.

Siswa dikatakan telah memahami konsep bilangan bulat jika telah memenuhi indikator keberhasilan pembelajaran pada siklus I dan siklus II. Adapun indikator keberhasilan itu terdiri dari: 1) Siklus I yaitu siswa dapat memahami konsep bilangan bulat; 2) Siklus II yaitu siswa mampu mengerjakan soal-soal bilangan bulat. Di samping itu, peneliti juga memaparkan kegiatan yang dilakukan selama proses belajar-mengajar oleh guru dan siswa berdasarkan hasil observasi. Kegiatan observasi dikatakan berhasil jika dalam kategori baik atau sangat baik. 


\section{Hasil dan PeMBahasan}

\section{A. Hasil}

Tahapan dalam penelitian ini dideskripsikan menjadi dua siklus. Pada siklus pertama terdiri dari dua pertemuan sedangkan pada siklus kedua terdiri dari satu pertemuan.

\section{Siklus 1}

Siklus pertama terdiri dari dua kali pertemuan. Penelitian dilakukan sesuai dengan alur yang telah dibuat yaitu sebagai berikut:

\section{a. Perencanaan}

Perencanaan penelitian dimulai dengan menyiapkan Rencana Pelaksanaan Pembelajaran (RPP). Selain menyiapkan Rencana Pelaksanaan Pembelajaran (RPP) hal yang perlu dipersiapkan oleh penulis yaitu media, lembar observasi aspek guru dan aspek siswa, dan soal tes. Berdasarkan pengamatan yang dilakukan oleh pengamat, persentase skor pada penilaian RPP siklus pertama 72,27\%..

\section{b. Pelaksanaan}

Pada siklus pertama, pelaksanaan pembelajaran dilakukan sebanyak dua kali pertemuan. Kegiatan belajar-mengajar yang terjadi pada siklus ini sesuai dengan RPP yang telah dirancang. Setiap pertemuan terdiri dari kegiatan pendahuluan, kegiatan inti dan kegiatan penutup.

Selama proses pembelajaran guru akan menggunakan cerita Si Unyil berbasis ICT sebagai media pembelajaran dan alat bantu untuk meningkatkan pemahaman konsep bilangan bulat. Kemudian dengan bantuan guru, siswa dilatih pemahaman konsep tentang bilangan bulat melalui media tersebut dan tanya jawab dengan pemberian soal-soal tentang bilang bulat.

\section{c. Pengamatan}

Proses pengamatan dilakukan oleh guru menggunakan lembar observasi yang terdiri dari beberapa komponen berikut:

\section{1) Komponen Guru}

Berdasarkan hasil pengamatan yang dilakukan oleh observer selama kegiatan pembelajaran pada siklus 1 yang dilakukan sebanyak dua kali pertemuan, pelaksanaan aspek guru dalam pembelajaran menggunakan belum tercapai secara maksimal. Hal ini terlihat dari penyampaian tujuan pembelajaran belum semuanya terlaksana seperti yang tertulis pada rencana pelaksanaan.

Bahasa yang digunakan guru mudah dipahami oleh siswa. Sehingga siswa menjadi kebingungan ketika guru menjelaskan tentang tujuan pembelajaran. Selain itu guru juga belum menggunakan cerita Si Unyil berbasis ICT secara maksimal sehingga siswa kurang memahami materi bilangan bulat. Ketika guru menggunakan media, guru kurang menjelaskan materi tentang bilangan bulat yang ada pada cerita Si Unyil siklus pertama. Di samping itu, guru kurang memberikan contoh soal bilangan bulat yang beragam sebagai tambahan bagi siswa.

Ketika menjelaskan kejelasan suara yang dijelaskan cukup dan sudah ada 
kekomunikatifan dan keluwesan sikap antara guru dan siswa. Guru kurang tampak antusias dalam mengajar menggunakan media berupa cerita si Unyil. Berdasarkan penjelasan di atas, diperoleh persentase skor pelaksanaan dari aspek guru pada awal siklus yaitu $76,00 \%$.

\section{2) Komponen Siswa}

Pada siklus pertama, pelaksanaan komponen siswa belum terlaksana maksimal. Ketika proses belajar-mengajar berlangsung tidak semua siswa memperhatikan cerita Si Unyil berbasis ICT yang ditayangkan oleh guru.

Di samping itu, siswa kurang aktif bertanya dan kurang aktif mengajukan ide. Saat pembelajaran berlangsung pun, siswa kurang terfokus dan kurang antusias pada materi. Hal ini sangat bertolak belakang dengan kedisiplinan siswa yang sangat baik dimana siswa selalu hadir saat pembelajaran, datang dan pulang tepat waktu bahkan mereka mempunyai jam khusus untuk berdoa. Siswa juga mengerjakan semua tugas, mengumpulkan tugas tepat waktu dan mengerjakan semua tugas sesuai dengan perintah. Berdasarkan penjelasan di atas, diperoleh persentase skor pelaksanaan dari aspek siswa siklus pertama yaitu 78,00\%.

\section{3) Komponen Hasil Belajar}

Hasil belajar diperoleh melalui penilaian pada ranah kognitif yaitu dengan memberikan soal tes. Tes berbentuk essai berjumlah 5 soal tentang bilangan bulat. Di tahap awal, siswa diberikan pretest (tes awal) dan posttest (tes akhir) pada pertemuan kedua. Kriteria Ketuntasan Minimal (KKM) di sekolah ini adalah 70.

Rata-rata nilai pretest siswa sebesar 29,26 dimana hanya 2 orang dari 26 orang yang mencapai KKM (sebesar 7,69\%). Sedangkan hasil posttest pada siklus pertama dengan nilai rata-rata 57,84 dimana hanya 9 orang dari 26 orang yang mencapai KKM (sebesar 34,61\%).

Berdasarkan kolaborasi peneliti dengan guru kelas sebagai observer disimpulkan pembelajaran pada siklus pertama belum terlaksana dengan baik artinya masih terdapat beberapa kekurangan. Maka dari itu, guru dan peneliti berusaha memperbaiki kekurangan yang terjadi pada siklus I peneliti melanjutkan ke siklus II.

\section{c. Refleksi}

Berdasarkan analisis data yang telah diuraikan terlihat bahwa pelaksanaan penelitian baik dari komponen guru, siswa dan hasil belajar belum terlaksana dan tercapai secara maksimal. Agar terjadinya peningkatan maka guru diharapkan mampu menggunakan kalimat yang mudah dipahami oleh siswa dan siswa mampu memahami proses penyampaian materi oleh guru.

Di samping itu, guru harus berusaha meningkatkan kemampuan pemahaman konsep siswa melalui serangkaian kegiatan belajar yang diikuti oleh siswa. 


\section{Siklus Kedua}

Tahapan pada siklus kedua seperti halnya dengan siklus pertama dengan alur sebagai berikut:

\section{a. Perencanaan}

Perencanaan penelitian pada siklus pertama diperbaiki di siklus kedua. Selain menyiapkan Rencana Pelaksanaan Pembelajaran (RPP) hal yang perlu dipersiapkan oleh penulis yaitu media, lembar observasi aspek guru dan aspek siswa, dan soal tes. Melalui hasil observasi yang dilakukan oleh observer diperoleh skor pada penilaian RPP alur kedua $87,25 \%$.

\section{b. Pelaksanaan}

Pada saat proses pembelajaran guru akan menggunakan cerita Si Unyil berbasis ICT sebagai media pembelajaran dalam membantu siswa memahami konsep tentang bilangan bulat. Kemudian dengan bantuan guru, siswa dilatih pemahaman konsep tentang bilangan bulat melalui media tersebut dan tanya jawab dengan pemberian soal-soal tentang bilang bulat.

\section{c. Pengamatan}

Proses observasi berpedoman pada lembar observasi yang dilakukan oleh peneliti yang terdiri dari beberapa komponen berikut:

\section{1) Komponen Guru}

Melalui hasil observasi yang dilakukan selama kegiatan belajar-mengajar pada siklus kedua yang dilakukan sebanyak satu kali pertemuan, pelaksanaan aspek guru dalam pembelajaran menggunakan belum memperoleh hasil yang diharapkan. Hal ini dibuktikan dari cara penyampaian tujuan pembelajaran sudah terlaksana dengan baik seperti yang tertulis pada rencana pelaksanaan.

Guru telah berkomunikasi dan interaksi dengan bahasa yang mudah dimengerti dan dipahami oleh siswa. Sehingga diperoleh hasil yaitu kemampuan pemahaman konsep siswa lebih baik dari sebelumnya. Terutama ketika guru menjelaskan tentang tujuan pembelajaran. Selain itu guru juga sudah mulai terbiasa menggunakan cerita Si Unyil berbasis ICT secara maksimal sehingga siswa lebih memahami materi bilangan bulat.

Di samping itu, pada siklus kedua ketika guru menjelaskan suarasudah cukup jelas dan sudah ada kekomunikatifan dan keluwesan sikap antara guru dan siswa. Guru tampak antusias dalam mengajar menggunakan media berupa cerita si Unyil. Di samping itu, guru dapat lebih peduli terhadap siswa dan adanya pemberian penghargaan dalam bentuk pujian bagi siswa yang mampu menyelesaikan soal dengan jawaban yang benar. Berdasarkan penjelasan di atas diperoleh persentase skor pelaksanaan dari aspek guru siklus kedua yaitu 88,50\%.

\section{2) Komponen Siswa}

Melalui proses observasi yang dilakukan oleh observer selama kegiatan belajarmengajar di siklus kedua, pelaksanaan komponen siswa sudah terlaksana dengan maksimal. Ketika kegiatan belajarmengajar berlangsung, lebih dari setengah siswa menonton cerita Si Unyil berbasis 
ICT yang ditayangkan oleh guru. Di samping itu, siswa lebih aktif bertanya dan mengajukan ide.

\section{3) Komponen Hasil Belajar}

Hasil belajar diperoleh melalui penilaian pada ranah kognitif yaitu dengan memberikan soal tes sama seperti siklus pertama (indikator dan bobot kesulitan soal sama tapi berbeda bentuk soalnya).

Nilai rata-rata yang diperoleh dari posttest sebesar 71,19 dimana ada 19 orang siswa dari 26 orang yang mencapai KKM (sebesar 73,07\%). Berdasarkan kolaborasi peneliti dengan guru kelas sebagai observer disimpulkan pembelajaran pada siklus kedua telah terlaksana dengan baik. Berdasarkan penjelasan di atas, diperoleh persentase skor pelaksanaan dari aspek hasil belajar pada siklus kedua yaitu $83,25 \%$.

\section{d. Refleksi}

Berdasarkan hasil refleksi memperlihatkan bahwa hasil belajar kognitif siswa meningkat pada siklus kedua seperti Gambar 1. Sehingga penelitian ini diberhentikan pada siklus kedua ini.

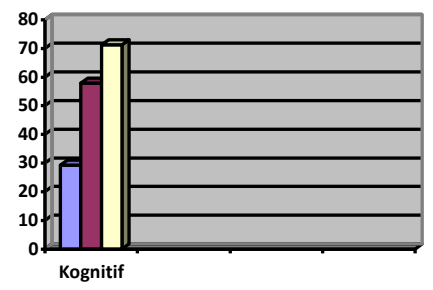

Gambar 1 Hasil Kognitif Pretest Siswa pada Siklus Pertama dan Kedua

Gambar 1 menunjukkan peningkatan hasil kognitif siswa meningkat baik dari segi pretest dan posttest pada kedua siklus yang dilakukan. Di samping peningkatan hasil kognitif, dari kedua siklus yang dilakukan oleh peneliti diperoleh hasil penilaian RPP, komponen guru, dan komponen siswa seperti pada Tabel 1.

Tabel 1.

Hasil Penilaian RPP, Komponen Guru, dan Komponen Siswa

\begin{tabular}{|llll}
\hline No & $\begin{array}{l}\text { Aspek yang } \\
\text { dinilai }\end{array}$ & $\begin{array}{l}\text { Siklus } \\
\text { Pertama }\end{array}$ & $\begin{array}{l}\text { Siklus } \\
\text { Kedua }\end{array}$ \\
\hline 1 & RPP & $72,27 \%$ & $87,25 \%$ \\
\hline 2 & $\begin{array}{l}\text { Komponen } \\
\text { guru }\end{array}$ & $76,00 \%$ & $88,50 \%$ \\
\hline 3 & $\begin{array}{l}\text { Komponen } \\
\text { siswa }\end{array}$ & $78,00 \%$ & $83,25 \%$ \\
\hline
\end{tabular}

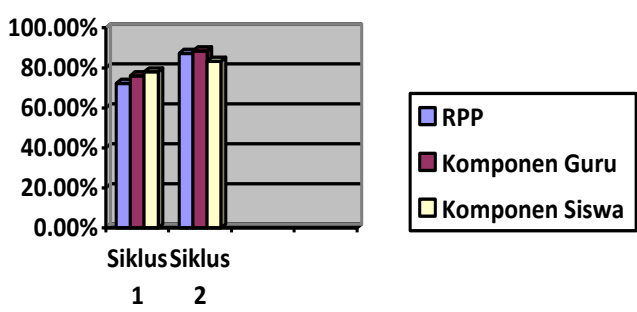

Gambar 2. Hasil Penilaian RPP, Komponen Guru, dan Komponen Siswa

Gambar 1 dan 2 memperlihatkan adanya peningkatan dari siklus pertama ke siklus kedua baik dari segi RPP, aspek guru maupun aspek siswa. Adapun peningkatannya sebagai berikut: 1) peningkatan pada segi RPP sebesar 14,98\%; 2) peningkatan pada komponen guru sebesar 12,5\%; 3) peningkatan pada komponen siswa sebesar 5,25\%.

\section{B. Pembahasan}

Pada tahap awal pelaksanaan penelitian, peneliti melakukan hal-hal berikut: 
1. Peneliti melaksanakan pengumpulan data berupa wawancara kepada guru bidang studi matematika kelas VII.A.

2. Peneliti mulai melakukan hasil observasi kelas.

3. Peneliti berkoordinasi dengan guru matematika terkait dengan pelaksanaan kegiatan penelitian antara lain: pretest (tes awal), penggunaan media cerita $\mathrm{Si}$ Unyil berbasis ICT dalam meningkatkan pemahaman konsep bilangan bulat, pelaksanaan penelitian pada kedua dan posttest (tes akhir) yang diberikan kepada siswa.

4. Guru bersama peneliti memberikan pretest (tes awal) tentang bilangan bulat. Soal pretest terdiri dari 5 soal essai. Pada pretest awal diperoleh hasil hanya 2 orang dari 26 orang yang mencapai KKM (sebesar 7,69\%)

5. Guru melaksanakan penelitian siklus 1 menggunakan cerita SI Unyil berbasis ICT seperti Gambar 3.

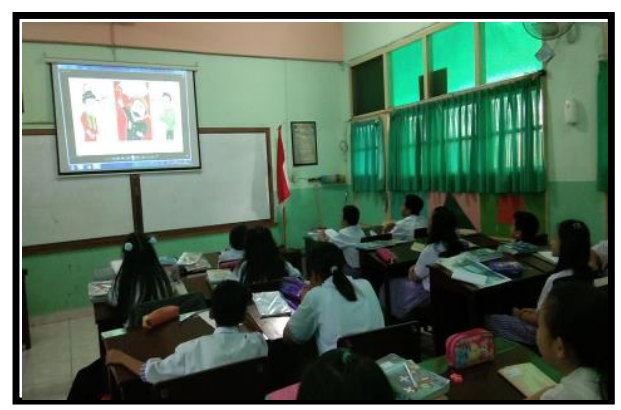

Gambar 3. Guru Menggunakan Cerita Si Unyil Berbasis ICT

6. Guru melakukan sesi tanya jawab dan memberikan soal terkait dengan materi bilangan bulat. Selanjutnya, siswa aktif menyampaikan jawabannya dengan mengacungkan tangannya.
7. Guru memberikan posttest pada siklus pertama dan memberikan penilaian terhadap posttest. Berdasarkan hasil posttest didapat hasil terdapat 9 dari 26 orang siswa yang mencapai KKM (sebesar 34,61\%)

8. Belum tercapainya peningkatan pada siklus awal maka perlu dilakukan penelitian siklus kedua.

9. Guru memberikan posttest pada siklus 2 dan diperoleh hasil ada 19 orang dari 26 orang yang mencapai KKM (sebesar 73,07\%). Setelah selesai melakukan posttest, peneliti memberikan angket kepada seluruh siswa.

Hasil kuesioner dideskripsikan sebagai berikut:

a. Media berupa cerita Si Unyil berbasis ICT lebih bermanfaat untuk meningkatkan pemahaman konsep bilangan bulat mendapatkan tanggapan positif sebesar $77,27 \%$.

b. Media berupa cerita Si Unyil berbasis ICT mendorong saya untuk lebih mengenal materi bilangan bulat mendapatkan tanggapan positif sebesar $86,36 \%$.

c. Media berupa cerita Si Unyil berbasis ICT membantu saya dalam menyelesaikan persoalan dalam pelajaran Matematika mendapatkan tanggapan positif sebesar $72,72 \%$.

d. Media berupa cerita Si Unyil berbasis ICT menjadikan saya lebih aktif dalam belajar matematika mendapatkan tanggapan positif sebesar $81,81 \%$. 
e. Media pembelajaran berupa cerita Si Unyil berbasis ICT membuat materi bilangan bulat menjadi lebih sederhana mendapatkan tanggapan positif sebesar $77,27 \%$.

Hasil belajar pada kedua siklus ditinjau dari Kriteria Ketuntasan Minimal (KKM) seperti pada Tabel 2.

Tabel 2.

Ketuntasan Minimal (KKM) Siklus Pertama dan Siklus Kedua

\begin{tabular}{|c|c|c|c|c|}
\hline \multirow[t]{2}{*}{ Data } & \multirow{2}{*}{$\begin{array}{c}\text { Jumla } \\
\mathrm{h} \\
\text { Siswa }\end{array}$} & \multicolumn{2}{|c|}{$\begin{array}{c}\text { Ketntasan Hasil } \\
\text { Belajar }\end{array}$} & \multirow[t]{2}{*}{$\begin{array}{l}\text { Ketuntasa } \\
\text { n Klaksikal }\end{array}$} \\
\hline & & Tuntas & $\begin{array}{c}\text { Tidak } \\
\text { Tuntas }\end{array}$ & \\
\hline $\begin{array}{l}\text { Siklu } \\
\text { sI }\end{array}$ & 26 & $\begin{array}{c}9 \text { siswa } \\
(34,61 \\
\%)\end{array}$ & $\begin{array}{c}17 \text { siswa } \\
(65,39 \% \\
)\end{array}$ & $\begin{array}{l}\text { Tidak } \\
\text { Tuntas }\end{array}$ \\
\hline $\begin{array}{l}\text { Siklu } \\
\text { s II }\end{array}$ & 26 & $\begin{array}{c}19 \\
\text { siswa } \\
(73,07 \\
\%)\end{array}$ & $\begin{array}{c}7 \text { siswa } \\
(26,93 \% \\
)\end{array}$ & Tuntas \\
\hline
\end{tabular}

Berdasarkan Tabel 2 terlihat hasil belajar siswa meningkat dari siklus pertama ke siklus kedua. Adapun Kriteria Ketuntasan Minimal (KKM) yang ditentukan SMP Xaverius 6 adalah 70. Pada siklus pertama terlihat hasil ketuntasan belajar siswa sebesar 34,61\% (terdapat 9 dari 26 orang yang mencapai ketuntasan) dan pada siklus kedua sudah mencapai ketuntasan klasikal yaitu 73,07\% (terdapat 19 orang dari 26 orang yang mencapai ketuntasan).

Berdasarkan data tersebut terlihat bahwa persentasi hasil belajar siswa meningkat sebesar 38,46\% (berdasarkan KKM yang telah ditetapkan pihak sekolah). Peningkatan hasil belajar itu sejalan dengan peningkatan pemahaman konsep siswa dalam penelitian Pamungkas \& Afriansyah (2017), yang di dalam penelitian ini melalui cerita Si Unyil berbasis ICT pada materi bilangan bulat.

\section{KESIMPULAN}

Berdasarkan hasil PTK terjadi peningkatan pemahaman konsep bilangan bulat yang ditunjukkan dari peningkatan hasil belajar siswa selama proses pembelajaran menggunakan cerita Si Unyil berbasis ICT pada materi bilangan bulat siswa kelas VII.A SMP Xaverius 6 Palembang. Hasil belajar siswa pada siklus pertama sebesar 57,84 mengalami peningkatan menjadi 71,19 di siklus kedua. Hasil tersebut merupakan hasil belajar siswa pada aspek kognitif.

Dengan demikian guru dapat menggunakan cerita Si Unyil berbasis ICT sebagai media pembelajaran matematika materi bilangan bulat karena penggunaan cerita Si Unyil berbasis ICT dalam proses pembelajaran dapat meningkatkan hasil belajar siswa dan pemahaman konsep siswa tentang bilangan bulat di kelas VII di SMP Xaverius 6 Palembang.

\section{UCAPAN TERIMA KASIH}

Peneliti menyampaikan rasa terima kasih kepada Direktorat Riset dan Pengabdian Masyarakat: Direktorat Jenderal Penguatan Riset dan Pengembangan Kementerian Riset, Teknologi, dan Pendidikan Tinggi yang telah memberikan bantuan berupa dana hibah Penelitian Dosen Pemula Tahun 
Anggaran 2019 sehingga peneliti dapat menyelesaikan penelitian ini.

\section{Daftar Pustaka}

Afriansyah, E. A. (2014). What Students' Thinking about Contextual Problems is. International Seminar on Innovation in Mathematics and Mathematics Education. Innovation and Technology for Mathematic, 279288.

Afriansyah, E. A. (2016). The Use of Realistic Approach to Enhance Students' Mathematical Problem Solving Skills. International Conference on Elementary and Teacher Education ICETE.

Asep, J., \& Abdul, H. (2010). Evaluasi Pembelajaran. Yogyakarta: Multi Pressindo.

Emzir. (2012). Metodologi Penelitian Pendidikan Kualitatif dan Kuantitatif. Bandung: Rajagrafindo Persada.

Farida. (2015). Mengembangkan Kemampuan Pemahaman Konsep Peserta Didik Melalui Pembelajaran Berbasis VCD. Al-Jabar: Jurnal Pendidikan Matematika, 6(1), 25-32.

Firdaus, D. A., \& Afriansyah, E. A. (2016). Pembelajaran Kooperatif Tipe Team Assisted Individually untuk Meningkatkan Kemampuan Pemahaman Matematis Siswa Sekolah Menengah Pertama. Jurnal Pendidikan Matematika RAFA, 2(1), 104-122.

Hartati, S., Abdullah, I., Haji, S. (2018). Pengaruh Kemampuan Pemahaman
Konsep, Kemampuan Komunikasi dan Koneksi Terhadap Kemampuan Pemecahan Masalah, Jurnal Pendidikan Matematika, 11(2), 41-59. Ismawanto. (2014). Pengembangan CD Interaktif Berbantuan Swishmax sengan Model Etnomatematika pada Materi Bangun Ruang Sisi Datar Kelas VIII Semester II. Prosiding Mathematics and Sciences Forum 2014, 2(2), 527534.

Kilpatrick, J., Swafford, J., \& Findell, B. (2001). Adding it up: helping children learn mathematics. Wasington DC: National Academy Press.

Brinus, K. S. W., Makur, A. P., \& Nendi, F. (2019). Pengaruh Model Pembelajaran Kontekstual terhadap Pemahaman Konsep Matematika Siswa SMP. Mosharafa: Jurnal Pendidikan Matematika, 8(2), 261-272

NCTM. (2000). Principles and Standars for School Mathematics. Reston, VA: NCTM.

Nuraeni, Y., \& Afriansyah, E. A. (2016). Peningkatan Kemampuan Pemahaman Matematis Siswa Melalui Pembelajaran Kooperatif Tipe Rotating Trio Exchange. Jurnal Inovasi Pendidikan Dasar, 1(2), 85-94.

Pamungkas, Y., \& Afriansyah, E. A. (2017). Aptitude Treatment Interaction terhadap Kemampuan Pemahaman Matematis Siswa. Jurnal Pendidikan Matematika RAFA, 3(1), 122-130.

Purwanti, dkk. (2016). Pengaruh Pembelajaran Berbatuan Geogebra 
terhadap Pemahaman Konsep

Matematis ditinjau dari Gaya Kognitif.

Al-Jabar: Jurnal Pendidikan

Matematika, 7(1), 115-122.

Ridia, N. S., \& Afriansyah, E. A. (2019).

Perbandingan

Kemampuan

Pemahaman Matematis Siswa melalui

Auditory Intellectualy Repetition dan

Student Teams Achievement Division.

Mosharafa: Jurnal Pendidikan

Matematika, 8(3), 515-526.

Runtukahu, J. T., \& Kondou, S. (2014).

Pembelajaran Matematika Dasar bagi

Anak Berkesulitan Belajar. Yogyakarta:

Ar-Ruz Media.

Sapilin, Adisantoso, P., \& Taufik, M. (2019).

Peningkatan Pemahaman Konsep

Peserta Didik dengan Model Discovery

Learning pada Materi Fungsi Invers.

Mosharafa: Jurnal Pendidikan

Matematika, 8(2), 285-295

Sundayana, R. (2015). Media dan Alat

Peraga Pembelajaran Matematika.

Bandung: Alfabeta.

Supriatna, R., \& Afriansyah, E. A. (2018).

Kemampuan Pemahaman Matematis

Peserta Didik melalui Cooperative

Learning Tipe Pair Checks VS Problem

Based Learning. JPMI (Jurnal

Pendidikan Matematika Indonesia),

3(1), 1-6.

Wahyuningtyas, D. T., \&lskandar, L. (2016).

Meningkatkan Pemahaman Konsep

Perkalian dan Pembagian Bilangan

Bulat Menggunakan Media

Wayangmatika, Jurnal Pancaran, 5(3),

51-60.
Warmi. (2019). Pemahaman Konsep Matematis Siswa Kelas VIII pada Materi Lingkaran. Mosharafa: Jurnal Pendidikan Matematika, 8(2), 297-306.

\section{Riwayat Hidup PenUlis}

\section{Lisnani, S.Pd., M.Pd.}

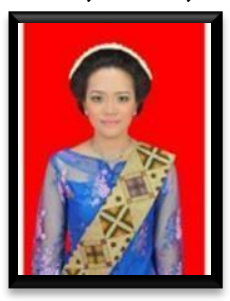

Lahir di Palembang, 19

September 1987. Studi: S1 Pendidikan Fisika di Universitas PGRI Palembang, tahun 2006 dan lulus tahun 2010; S2 Pendidikan Matematika

di Universitas Sriwijaya Palembang, Sumatera Selatan; Pada tahun 2019, penulis sedang studi S3 Doktor Pendidikan Matematika di Universitas Sriwijaya.

\section{Yohanes Heri Pranoto, M.Pd.}

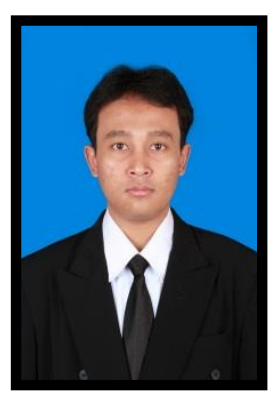

is a lecturer in English Language Teaching at English Language Education Study Program, Humanities and Education Faculty, Musi Charitas Catholic University Palembang, South Sumatera. He earned his undergraduate degree of English Education at Sanata Dharma University, Yogyakarta, and his postgraduate degree at Sriwijaya University, South Sumatera. 